University of Nebraska - Lincoln

DigitalCommons@University of Nebraska - Lincoln

Agronomy \& Horticulture -- Faculty Publications

Agronomy and Horticulture Department

1954

\title{
A Seventeen-Year Study of Plant Succession in Prairie
}

J. E. Weaver

University of Nebraska-Lincoln

Follow this and additional works at: https://digitalcommons.unl.edu/agronomyfacpub

Part of the Plant Sciences Commons

Weaver, J. E., "A Seventeen-Year Study of Plant Succession in Prairie" (1954). Agronomy \& Horticulture -Faculty Publications. 434.

https://digitalcommons.unl.edu/agronomyfacpub/434

This Article is brought to you for free and open access by the Agronomy and Horticulture Department at DigitalCommons@University of Nebraska - Lincoln. It has been accepted for inclusion in Agronomy \& Horticulture -Faculty Publications by an authorized administrator of DigitalCommons@University of Nebraska - Lincoln. 


\title{
A SEVENTEEN-YEAR STUDY OF PLANT SUCCESSION IN PRAIRIE ${ }^{1}$
}

\author{
J. E. Weaver
}

THE NATURE AND RATE of regeneration of a 23yr.-old bluestem pasture under complete protection from grazing were studied near Lincoln, Nebraska. The pasture adjoined a large tract of True Prairie, $0.5 \mathrm{mi}$. long and $0.25 \mathrm{mi}$. wide, of which it was originally a part. The prairie, of the upland midgrass type, had not been grazed for at least $40 \mathrm{yr}$., and probably only moderately since the disappearance of the bison. It is used for the production of hay and is mowed annually in late summer or autumn. A portion of the pasture adjoining the prairie was separately fenced and thus closed to livestock in the spring of 1937. This part was 31 rods long and 4.5 rods wide. It extended northward from the top of a low hill down a gentle slope and included its nearly level but well drained base. On the hilltop and upper slope the silty clay loam of the A horizon was 10-12 in. deep; the silt loam of the lowland has an A horizon 20 in. deep. Both soil types have deep, permeable B horizons. Average annual precipitation is $27.9 \mathrm{in}$.

The native pasture adjoining the prairie had apparently never been greatly overgrazed. It was studied and described in 1932 as in good range condition and was characterized by about half dominance of bluestems (Andropogon) and other prairie grasses and half of Kentucky bluegrass (Poa pratensis). ${ }^{2}$ The cover was practically intact, annual weedy species were few, and only a modicum of the usual perennial pasture weeds occurred.

Great deterioration of the pasture occurred during the first three years of the long drought (1934$36)$. In the enclosed portion in 1937 both little bluestem (Andropogon scoparius) and big bluestem $(A$. gerardi) occurred very sparingly. Bluegrass remained only in scattered patches ranging from a few sq. d. to a sq. m. in area. Sand dropseed (Sporobolus cryptandrus) varied in occurrence from sparse to abundant as did also side-oats grama (Bouteloua curtipendula). Small amounts of Junegrass (Koeleria cristata) and a few other native grasses were found. A few patches of blue grama (Bouteloua gracilis) were scattered on hillside and lowland. Dense patches of peppergrass (Lepidium densiflorum) occurred throughout much of the pasture and Pursh's plantain (Plantago purshii) was very abundant in widely distributed patches. These, with smooth goldenrod (Solidago glaber. rima), many-flowered aster (Aster multiflorus), and horseweed (Leptilon canadense), were the major constituents of the weedy flora (fig. 1-3).

\footnotetext{
1 Received for publication July 17, 1953.

2 Nomenclature of grasses follows Hitchcock's "Manual of Grasses of the United States" Second edition; that of other plants, Britton and Brown's "Illustrated Flora," unless other authority is given.
}

The prairie on the north slope adjoining this portion of the pasture had suffered only moderately from drought, except the driest upland part. Severe drought occurred each growing season until 1942, but conditions were favorable to growth in spring and early summer of 1938 and 1941. Soil sampling to depths of $6 \mathrm{ft}$. revealed that during the entire period the vegetation depended chiefly upon current rainfall for its water for growth.

This study began during the period of great drought. Chief development during the first four years was the repopulating of the semibared soil with annual weeds, a few very drought-resistant prairie forbs, and xeric grasses. Invading sand dropseed from Mixed Prairie and the droughtresistant side-oats grama, now released from competition with the bluestems, became the dominant grasses in a cover that became very dense. Rate of succession was greatly retarded when moist soil prevailed since this population was only gradually replaced by former prairie species, over a period of about ten years. Big bluestem and little bluestem were the chief grasses which increased year by year and finally replaced vegetation of the drought years, but a dense sod of bluegrass also played an important part. The re-establishment of prairie and the adjustments of vegetation in the process of stabilization were traced until the autumn of 1953.

REPopulation of SEMIBARED AREAS.-Five different lots of permanent, meter quadrats were established in 1937 in which the increase or decrease of each species was ascertained quantitatively by the stem-count method. Ten of these were marked out at random in widely distributed areas where sand dropseed dominated; 10 were similarly located in small areas revealing remnants of little bluestem; and 10 others were placed where relict patches of bluegrass persisted. A fourth lot of 10 was scattered widely to include small patches of blue grama, and 3 quadrats were established in representative bared areas occupied by peppergrass.

This method, though slow and laborious, was selected as best to study the fragments of droughtdamaged plants and the scattered individuals of invaders. Succession in grassland can be followed only by exact methods of counting, measuring, mapping, and comparing the vegetation year after year. In addition to changes recorded in quadrats, the more apparent variations in the vegetation in the entire protected pasture were studied throughout each summer. Thirteen species of grasses and sedges, 19 of native forbs, and 13 ruderals composed the total vegetation in the 43 quadrats in 1937; this number (45) increased to 58 four years later. 


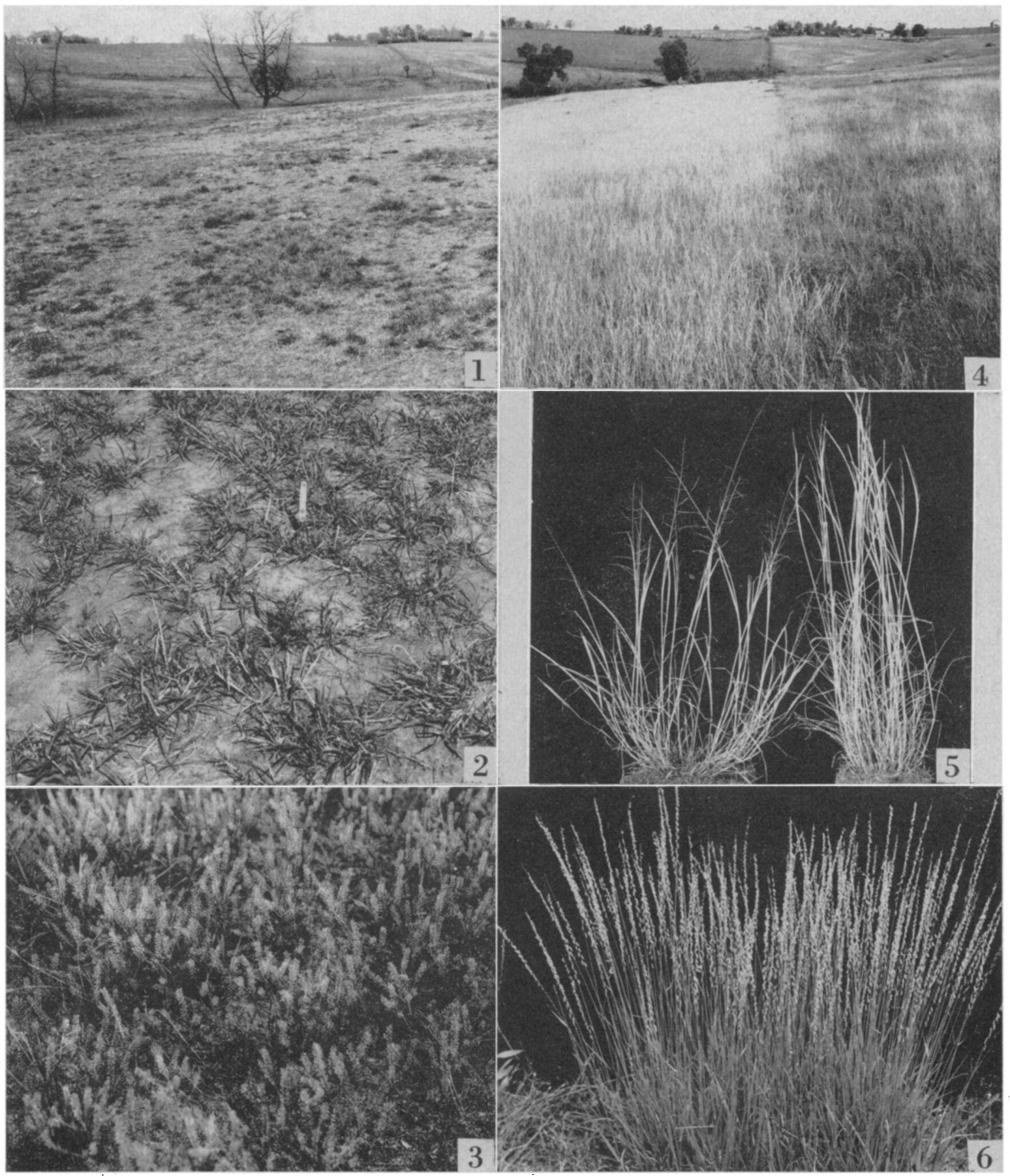

Fig. 1-3. Degenerated prairie when study was begun in 1937.-Fig. 1. . Relict patches and bunches of Kentucky bluegrass (Poa pratensis).-Fig. 2. Thin stand of sand dropseed (Sporobolus cryptandrus).-Fig. 3. Characteristic stand of peppergrass (Lepidium densiflorum).

Fig. 4-6. Subsere (recovering prairie) near the end of the drought, in autumn of 1940.-Fig. 4. Sharp line of demarcation between subsere (left) and prairie (right) in September. Dried flower stalks of sand dropseed with some side-oats grama obscure other vegetation in the old pasture. The chief plant of light color in prairie is side-oats grama.-Fig. 5 . Bunches of sand dropseed, about 26 in. high, showing the spreading habit in open vegetation (left) and more erect stems when surrounded by competing mid-grasses.-Fig. 6. A large bunch of side-oats grama about $2.5 \mathrm{ft}$. tall (other vegetation removed) showing its excellent development during the dry years. 
Summary of succession in all quadrats. ${ }^{3}$-Eluegrass comprised 56 per cent of the total grasses in 1937, but drought reduced it to only 3 per cent the next year. Then it more than tripled in amount; but lost again in the 1939 drought.

Sand dropseed comprised 26 per cent of the total grasses. It continued to spread during 1939-1940 when nearly all other grasses decreased, making a total gain of 137 per cent. In hundreds of stems in the $10 \mathrm{sq} . \mathrm{m}$. of sand dropseed quadrats, the numbers from 1937 to 1940 were $62,73,90$, and 121 . Originally present in $1,841 \mathrm{sq}$. $\mathrm{dm}$. of the 43 quadrats, it finally occurred in 1,953. In the three quadrats where peppergrass alone was abundant, sand dropseed rapidly invaded and with side-oats grama became very abundant.

Side-oats grama increased even more rapidly than did sand dropseed. The 4-yr. gain was 413 per cent. Initially it occurred in $500 \mathrm{sq}$. dm., but finally in about 2.5 times this number. Little bluestem made a total gain of more than fourfold in number of stems by 1940, but the number of units in which it occurred increased only from 549 to 822 . Very few seedling bluestems of either species were found.

Amount of big bluestem fluctuated considerably during the dry years but the total gain was 362 per cent. It had spread from 580 to 1,245 unit areas. Hairy grama (Bouteloua hirsuta), June-grass, and Penn sedge (Carex pennsylvanica) increased steadily; the total gains were 209, 333, and 406 per cent, respectively. Penn sedge doubled its area, Junegrass gained but slightly, and hairy grama lost area formerly occupied.

No seedling grasses were found in 1937 but grass seedlings, especially those of sand dropseed and side-oats grama, were abundant in 1939-40. In grassland after several years of drought, a good seed crop must precede an abundance of seedlings (Weaver and Mueller, 1942). Changes in the composition of the grasses and grass-like plants during the 4-yr. period are shown in table 1. Only 5 of the 26 native forbs growing in the quadrats were of major importance. Together they constituted 90 per cent of the total native forb population. Rough pennroyal (Hedeoma hispida), Pursh's plantain, and daisy fleabane (Erigeron ramosus) were the

3 Tables and charts on details of changes in each group of quadrats with special reference to pasture management are presented elsewhere by Weaver and Hansen, 1941. chief forbs in 1937, but all decreased 90 per cent or more by 1940 and lost heavily in unit areas occupied. Conversely, many-flowered aster and smooth goldenrod increased very greatly both in numbers and frequency.

Only 3 of the 17 species of weeds were of outstanding importance. Horseweed formed 49 per cent, peppergrass 44, and little barley (Hordeum pusillum), 7 per cent of the ruderal fraction of the vegetation in 1937. The first two were insignificant after 1937, but little barley increased nearly 600 per cent in 1938, composed 87 per cent of the ruderals, and was the chief weed thereafter.

Resumé of changes.-The second year of succession was one of good recovery despite midsummer drought. The dominant grass everywhere was sand dropseed with side-oats grama second in importance but of much lower rank and with the plants widely scattered. In many places sand dropseed covered the soil almost completely, the foliage cover was 90 per cent late in July when the general grass level was about $12 \mathrm{in}$. and flower stalks were 2.5 to $3 \mathrm{ft}$. tall (Weaver, 1939). At a distance of a few yards, except for certain weeds, the pasture appeared to be completely dominated by sand dropseed and a sparse to moderate mixture of side-oats grama. A considerable part of the increase of sand dropseed resulted from abundant seedlings. All other grasses were far less abundant than the preceding; their order of importance was little bluestem, big bluestem, blue grama and hairy grama, June-grass, and bluegrass. Although these prairie grasses were not abundant, considering the area as a whole, yet they did dominate in many scattered square meters, a fact of much importance since it distinctly indicated the beginning of the return of prairie grasses.

In 1940, the fourth year of succession, sand dropseed alone still dominated in many places, and in mixture with side-oats grama in others. In parts of the area it was well intermixed with the bluestems. June-grass and Penn sedge were far more common than before. Occasional bunches of hairy grama, tall dropseed (Sporobolus asper), prairie dropseed (S. heterolepis), and plains muhly (Muhlenbergia cuspidata) occurred. On the lower ground the flower stalks of bluegrass were scattered thinly. Goldenrods were fewer and much dwarfed; they had been thinned greatly as the grasses increased; often only the outlines of former dense

TABLE 1. Percentage composition of grasses and sedges (except Bouteloua gracilis) in pasture in 1937 and 1940 based upon the number of stems.

\begin{tabular}{|c|c|c|c|c|c|}
\hline \multirow[t]{2}{*}{ Species } & \multicolumn{2}{|c|}{$\%$ Composition } & \multirow[t]{2}{*}{ Species } & \multicolumn{2}{|c|}{ \% Composition } \\
\hline & 1937 & 1940 & & 1937 & 1940 \\
\hline 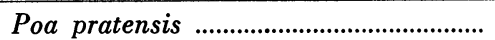 & 56 & 3 & Bouteloua hirsuta & 1.7 & 3 \\
\hline 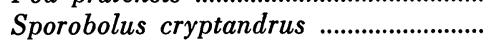 & 26 & 39 & 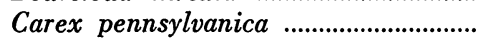 & 1 & 4 \\
\hline 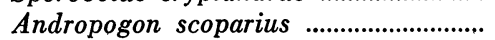 & 6 & 18.5 & 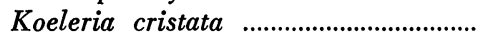 & 1 & 2.5 \\
\hline Bouteloua curtipendula ............................... & 4 & 14 & 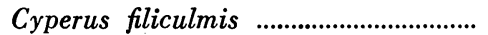 & 0 & 3 \\
\hline 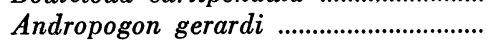 & 4 & 12 & 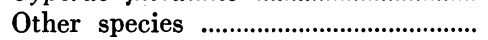 & 0.3 & 1 \\
\hline
\end{tabular}


patches remained. The patches of aster were likewise mostly very open, but the plants were taller than in the earlier stages in succession. The bunches of grass were much thicker, of greater height, and produced many more stems than earlier in the succession. In autumn where large bunches and patches of big bluestem were present, there were distinct openings in the general canopy of flower stalks afforded by sand dropseed and side-oats grama. The annual weed stage, especially the part composed of little barley, had nearly disappeared. Plantain likewise was inconspicuous. Weeds were of minor importance, and the impression was distinctly one of grasses (fig. 4-6).

Other measures of succession.-Changes in the vegetation were ascertained by several other methods. The following data are from Weaver and Hansen (1941). In early spring of 1939 the fence on the pasture side of the original exclosure was moved $20 \mathrm{ft}$. westward so as to enclose a new portion of the pasture. A third area of similar width and also parallel to the first was closed to cattle in early spring of 1940. Thus, in the summer of 1940 three stages in succession were available for study, one in an area in the first year of recovery and one in the second, in addition to the 4-yr.-old exclosure.

A series of quadrats were placed opposite each other across the long strips of these protected areas, and foliage cover and basal area were ascertained. In mid-June, 1940, foliage cover of the vegetation undergoing the first, second, and fourth year of protection was 30,57 , and 61 per cent, respectively. Basal area was 10,21 , and 20 per cent in the same sequence.

Diameter of bunches of little bluestem gradually increased with the progress of succession, but bunches of sand dropseed at first increased and then became smaller. This resulted from a more erect growth habit with increasing shade (fig. 5). Length of stems of both species increased rapidly and consistently under protection as did also their numbers. Increase in foliage as succession progressed was accompanied by greater accumulation of litter. This increase in vegetal mulch was very beneficial, especially in relation to conservation of precipitation.

The increased vigor of vegetation as expressed by its rate of development after repeated removal of the foliage was ascertained. Grasses were clipped 1.5 in. above the soil on June 1 , July 1 , and again on August 15. Foliage heights were measured on September 11 in pasture protected for the first, second, and fourth year, and in climax prairie. All six species used in this experiment gave a sequence of foliage heights, in the preceding order of protection, similar to those of little bluestem, which were 3.0, 3.2, 4.5 and 4.8 in., respectively. These data confirm other similar studies on recovery after clipping and reveal clearly the increased vigor resulting from greater food reserves under a longer period of protection.
REPLACEMENT OF DROUGHT POPULATION BY FORMER SPECIES OF PRAIRIE.- The great drought was temporarily broken by heavy rains in the spring of 1941. Conditions for growth were good until the last week in June. Then there began a severe midsummer drought. The vegetation lost its green color and dried. But it renewed growth after rains late in August. Only a few of the most droughtresistant grasses, as sand dropseed, side-oats grama, and blue grama, produced a small crop of flower stalks in the most favorable places. Unusually heavy rainfall occurred in 1942, and, with few exceptions, a good water content of soil was maintained at most soil-depths to $6 \mathrm{ft}$. throughout the growing season. The drought had been definitely broken, plants grew taller and the cover became denser. The summer of 1943 was an excellent one to promote growth. Accumulated water reserves resulted in good yields despite occasional deficient rainfall (Weaver and Bruner, 1945).

In quadrats dominated by sand dropseed this species decreased rapidly each year. Thus, in 1940 it composed 68 per cent of all the grasses, as measured by number of stems, but in 1943 only 35 per cent, despite the fact that the plants were more widely distributed. In the little-bluestem quadrats, where sand dropseed had usually ranked second until 1941, it produced such a large crop of seedlings that it greatly surpassed little bluestem for a single summer. After this it decreased from 14,000 to 3,000 stems. The plants were more widely distributed than in 1940.

Side-oats grama reached a maximum of 16 per cent of the total grass cover in sand-dropseed quadrats in 1942. It decreased sharply in 1943. In the little-bluestem quadrats it decreased about one-third from 1941 to 1943 . It also decreased considerably in frequency. As the more mesic grasses regained their vigor and became more abundant, the denser shade produced by them was the greatest cause of the marked decline of both sand dropseed and sideoats grama.

Little bluestem had not increased greatly in its own quadrats-from 8,000 to 9,500 stems-and but little in unit areas occupied. In the sand-dropseed quadrats it showed a considerable decrease in number of stems and a very great loss in number of unit areas in which it occurred. Big bluestem increased from 2,800 to 3,100 and 1,200 to 1,800 stems in the two groups of quadrats, respectively, from 1940 to 1943 . These gains were accompanied by decreased frequency. Bluestems had suffered greatly from the drought. But after 1942, widely scattered and long-dormant crowns revived. It has been shown that this frequently occurred after 5-7 yr. of deep dormancy during which new shoots were not produced (Weaver and Albertson, 1944).

Only 100 seedlings of grasses and less than half this number of seedling native forbs were found in 20 meter quadrats in 1942. Seedlings were also scarce under the heavy cover of vegetation in 1943, 

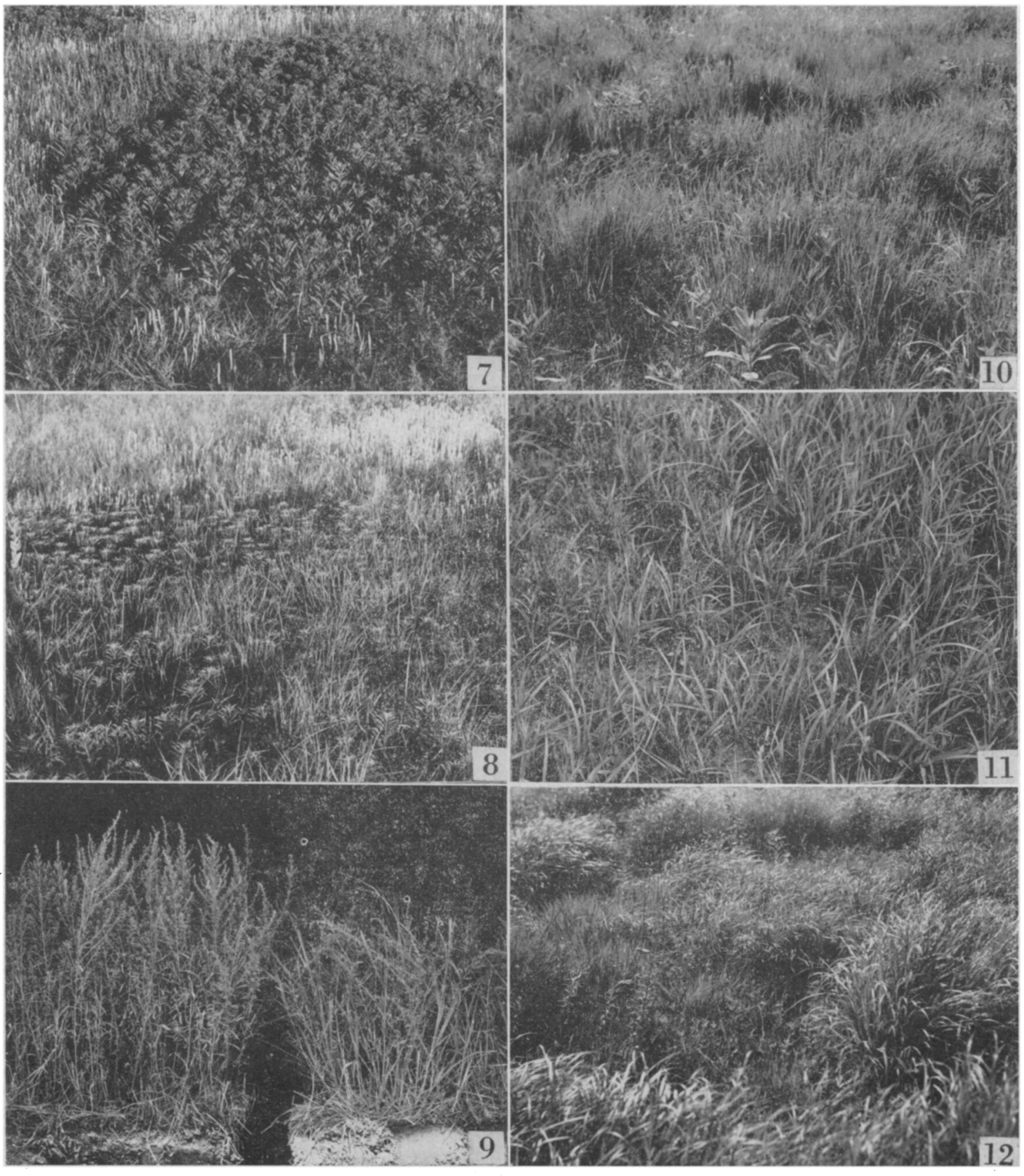

Fig. 7-9. Behavior of forbs in the subsere.-Fig. 7. Characteristic dense growth of smooth goldenrod (Solidago glaberrima) in subsere after 2 yr. of protection.-Fig. 8. Open growth of smooth goldenrod after 4 yr. of succession; formerly similar to that in fig. 7, it is giving way to competing grasses.-Fig. 8. Many-flowered aster (Aster multiflorus) during drought (left); on the right it is being thinned by the grasses.

Fig. 10-12. Regenerated prairie in 1952.-Fig. 10. Dense sod of little bluestem (Andropogon scoparius) developed on the upper hillside, mostly since 1945.-Fig. 11. Thick stand of nearly pure big bluestem (A. gerardi) typical of the mid portion of the area in May.-Fig. 12. Big bluestem alternating with patches of Kentucky bluegrass in the lower portion of the subsere area. 
although a good seed crop matured in 1942. In fact, the slowness of succession was due in part to the small number of seedlings. Consequently, increase in perennial plants resulted from tillering and production of shoots from rhizomes or other means of vegetative propagation. Penn sedge and June-grass increased greatly after 1941, when soil moisture became plentiful. Bluegrass also increased so rapidly that further stem counts of plants in its quadrats seemed impracticable. Its return by rhizome propagation was extremely rapid.

The basal area, originally 6 per cent, in the ten quadrats where blue grama occurred was ascertained annually, each square decimeter being estimated separately. In 1941 it averaged only 13 per cent, but a year later it had increased to 23 . This increase was due largely to the thickening of the stand within the mats rather than to their extension.

Three years after the great drought sand dropseed was still abundant in some places and occurred rather sparingly throughout. Bluegrass and sideoats grama with some bluestems dominated the upland and in parts of the lowland bluegrass and big bluestem formed a dense sod. The soil was well covered with vegetation. Practically all of the weedy annuals had disappeared and the perennial many-flowered aster and smooth goldenrod were greatly subdued (fig. 7-9). An understory of various minor prairie grasses, bluegrass, and forbs was developing. In the little-bluestem type common groupings were bluegrass with sand dropseed, bluegrass with aster, and sand dropseed with hairy chess (Bromus commutatus). The cover was becoming dense and a good mulch had accumulated. But several species of prairie grasses were still absent. This was also true of many forbs common in adjacent climax prairie. Also the lack of various community relationships indicated that succession was still incomplete.

The progress of succession was closely observed month by month each summer until 1948. Each of the four years was favorable to growth. During these years the little-bluestem type was slowly developing on the upland, largely from seedlings. Big bluestem became prominent here only after it had occupied much of the lower land. The dense sod of bluegrass on the lowland was less easily replaced by bluestems than was the thinner one on the drier, upper slope. Blue grama was being shaded out; year by year some of its small patches disappeared. Remnants of sand dropseed were becoming progressively' fewer and well-developed plants were not common. Side-oats grama also decreased as big bluestem, especially, thickened its stand. Ruderals became rare and many-flowered aster and smooth goldenrod were much less frequent. But various changes in the plant population were still to occur. These included the increase of former dominants; further suppression of drought dominants during the wetter phase 'of the climatic cycle; the disap- pearance or reduction to normal numbers of other relicts of drought populations; the re-establishment of the drought-depleted forb population and a new development of societies (Weaver, 1950).

Progress in development by 1948-49.-D During these years a thorough study of this regenerating prairie was made by Mentzer (1951) under the direction of the writer. Special attention was given during this period of good rainfall to the composition and structure of the subsere in comparison with that of the adjoining climax. Mapping the distribution and approximate abundance of all the more important grasses and forbs afforded an excellent means of direct and exact comparison of subsere and climax vegetation. Twelve areas, each $6 \times 12 \mathrm{ft}$., were mapped in subsere, and 12 similar ones, just opposite these, in climax prairie. The following data are from his study:

"A little bluestem type occupied the upper third of the north-facing slope; big bluestem type had developed on the mid-portion; and a big bluestemKentucky bluegrass type was found on the deeper and richer soil of the nearly level lower third of the subsere.

Little bluestem was sparse throughout, but it was more than three times as abundant in prairie as in pasture. Big bluestem in the little bluestem pasture type occurred sparingly and mostly in small bunches. Elsewhere, there was almost âs much of this grass in pasture as in prairie. Bluegrass was abundant and widely scattered in pasture, and always present but sparse in prairie. Blue grama occurred only in pasture and side-oats grama was more abundant there. Tall dropseed was abundant in prairie but rare in pasture. Sand dropseed occurred throughout the pasture where it invaded during the drought. It was not found in prairie. Forbs were not abundant in the subsere, even eight years after the drought, despite their large variety and abundance in the prairie."

Stiff sunflower (Helianthus scaberrimus) formed dense societies in prairie. The plants had extended into the pasture by means of rhizomes, one group to a distance of $18 \mathrm{ft}$. But not a single isolated sunflower was found in the subsere. In equal areas, two rods in width, extending parallel through prairie and pasture, numbers of stems of lead plant were 1,062 and 35 , respectively.

"The average air dry yield of prairie grasses (1948-49) was 24 per cent greater in prairie, but pasture grasses [including bluegrass, and invading, mostly weedy, grasses not found in climax prairie] yielded 60 per cent less than in the subsere. The yield of forbs was 120 per cent greater in prairie. Although the soil was fully occupied and a good mulch was re-established, the regular cover of climax prairie did not prevail and the understory was poorly developed."

The annual yield of prairie grasses in the subsere, based upon the prairie as 100 per cent, was found to be 8,18 , and 67 per cent at the end of 1 , 
2 , and $4 \mathrm{yr}$. of succession, respectively (Weaver and Hansen, 1941). But in 1948-1949 the bulk of subsere vegetation (77 per cent) was composed of prairie grasses (Mentzer, 1951). Thus, the subsere was much closer to the climax than it had been eight years earlier at the end of the drought.

RE-ESTABLISHMENT OF PRAIRIE.-Further recovery of the vegetation was studied during 1950-1953. In the upland area little bluestem, which had been sparse, became very abundant. Many of the older bunches were 4-6 in. wide, but a larger number ranged from 1 to 3 in. in width. These numerous smaller plants filled in much of the interspace. Big bluestem, formerly represented by only small tufts, had also made great gains. Conversely, the formerly abundant mats of bluegrass with sand dropseed, bluegrass with aster, and sand dropseed with hairy chess, were finally respresented only by a few suppressed relicts. Sand dropseed and side-oats grama steadily decreased and were now far less abundant. All these had been largely replaced by the bluestems. Little barley, rough pennyroyal, and other drought relicts were rare.

In 1952, fifty sq. ft. samples taken at random along predetermined lines, revealed that the basal area had been reduced to 18 per cent, which was very similar to that in prairie. This was mostly a result of the decrease in the sod-forming bluegrass. This basal area was composed of 59 per cent little bluestem, 31 per cent big bluestem, and only 3 per cent bluegrass. Side-oats grama was next most abundant, 3 per cent; Penn sedge and small panic grasses composed about 2 and ' 1 per cent, respectively. An excellent mulch occurred everywhere; blue grama had disappeared, and forbs were common.

Invasion of big bluestem into the small areas of blue grama has been carefully studied. The rhizomes advanced under the sod a few inches each year and extended 3-4 ft. into blue grama territory. Within the invaded area blue grama became thinner and more attenuated foot by foot as the tall competitor became thicker. The number of shoots gradually decreased until after 2-3 yr. only the dead and decaying plants of blue grama remained. Blue grama, sand dropseed, and certain other grasses and sedges were likewise shaded out as the number and size of bunches of little bluestem increased.

Comparison of this little-bluestem type with that in long-established prairie revealed several differences. The number of dominant grasses in a very large lot of meter quadrats was often only one, mostly two, but rarely were there three. In adjacent prairie there were nearly always two or three dominant grasses intermixed and often four. While large bunches of little bluestem were found, the sod-mat type was also common. Species of forbs were fewer in the subsere and the numbers were far less abundant than in prairie. Very few societies were encountered in subsere but these were of general occurrence in prairie.

Each year one observed the return of species to the recovering prairie. The entrance and spread of prairie dropseed, needle grass (Stipa spartea), and Indian grass (Sorghastrum nutans) have been studied. Societies of Petalostemum candidum and Psoralea argophylla are being formed on the lower slopes. Representatives of forbs that have only recently entered the area are Astragalus crassicarpus Nutt., Psoralea esculenta, Sisyrinchium campestre, Meriolix serrulata, Meibomia illinoensis and Delphinium virescens. One could profitably follow the incoming and redistribution of the prairie forbs and other adjustments within the community for many years. Thus, while prairie had been re-established or nearly so on this upper slope it was still not the usual excellent type of prairie with its rich and varied flora, despite the fact that $13 \mathrm{yr}$. had passed since its 4-yr. struggle for recovery during the drought.

Much of the big bluestem-bluegrass area on level lowland was laid off in 1.5-sq. m. areas and the percentage of the several dominants ascertained. There was practically no mixing of bluegrass and. big bluestem; alternating areas were occupied either by one species or the other. A moderate-to-dense. sod of big bluestem occurred almost in pure stands. But in the prairie the stand of this grass was nearly always more open and dominance was usually shared with switchgrass (Panicum virgatum), Indian grass, prairie dropseed, needle grass or little bluestem. Moreover, here the understory of lowgrowing grasses, sedges, and forbs was clearly apparent. The persistence with which bluegrass retained its hold in the old pasture was remarkable (Cf. Anderson, 1946). Big bluestem covered 58 per cent of the area, bluegrass 40 per cent, and little bluestem only 2. Examination, early in June, along many feet of the very definite lines of contact between these grass types showed no invasion of bluegrass in 1952, although the greatest advances by rhizomes of big bluestem are usually made early in spring (Mueller, 1941). A few coarse forbs occurred in the dense shade cast by big bluestem; there were many more forbs and several grasses and sedges intermixed with the bluegrass.

The mid-portion of the experimental area traversed by the ravine was nearly all clothed with big bluestem (83 per cent). Little bluestem occupied 11 per cent and bluegrass only about 6 per cent of this area. It too can now be considered almost typical lowland prairie; but undisturbed it will acquire a richer and much more diversified flora (fig. 10-12). In the level northern section the hold of bluegrass may not be entirely broken for many years. But if these are years with plentiful moisture the larger competitor by means of shade, rhizomes, and more extensive roots may spread over the entire area. With cessation of man's interference by mowing, it seems certain that the deep 
mulch formed by big bluestem would soon overwhelm the bluegrass.

In 1952 neither prairie nor subsere were mowed. Debris from lodged big bluestem occurred to a depth of 3-6 in. over the adjacent bluegrass. The following spring, bluegrass was greatly thinned or almost completely smothered under this mulch. The building of a large dam in the area and re-fencing for grazing were reasons for concluding this study.

This phenomenon of the return of vegetation nearly to its former natural condition-nature's putting back what was there in the first place-is summed up in the term, plant succession. In connection with pastures derived from True Prairie it is of great practical as well as scientific importance, since no pasture at any stage in the degeneration of this prairie produces continuously so great an amount of highly nutritious forage as do the native bluestems.

\section{SUMMARY}

Plant succession was studied in an old bluestem pasture under complete protection at Lincoln, Nebraska, from 1937 to 1953. About half of the vegetation was Kentucky bluegrass. The pasture adjoined a large area of True Prairie. Three years of drought had reduced the bluestems to 10 per cent of the cover; bluegrass and invading sand dropseed composed 56 and 26 per cent, respectively. All but
3 per cent of bluegrass died by the end of the great drought, 1940; sand dropseed had increased enormously and, with the xeric side-oats grama, almost completely dominated. But many less xeric prairie grasses were scattered throughout and indicated the return of prairie. Big bluestem on lower, more moist slopes and, later, little bluestem on upper hillsides slowly increased, following the drought, over a period of $13 \mathrm{yr}$. Succession was greatly retarded by the presence of the drought population and later by a sod of bluegrass which was rapidly established. Upper slopes are now clothed with about 60 per cent little bluestem, 30 per cent big bluestem, and only 3 per cent bluegrass. Lowland now supports extensive pure stands of big bluestem or alternate areas of big bluestem and bluegrass. Forbs were at first largely represented by a few prairie species which increased greatly, and by numerous annual weeds. Most prairie forbs were exterminated by grazing or by drought. Many have returned only slowly; some are now represented by a few plants; numerous others have not yet reentered the area. This is also true of various grasses. The regenerated prairie is approaching a dynamic equilibrium not greatly unlike the adjacent climax.

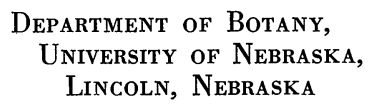

\section{LITERATURE CITED}

Anderson, W. A. 1946. Development of prairie at Iowa Lakeside Laboratory. Amer. Midl. Nat. 36: 431-455.

Mentzer, L. W. 1951. Studies on plant succession in True Prairie. Ecol. Monogr. 21: 255-267.

Mueller, I. M. 1941. An experimental study of rhizomes of certain prairie plants. Ecol. Monogr. 11: 165-188.

WEAVER, J. E. 1939. Increase of Sporobolus cryptandrus in pastures of eastern Nebraska. Ecology 20: 374-381.

- 1950. Stabilization of midwestern grassland. Ecol. Monogr. 20: 251-270.

- AND F. W. Albertson. 1944. Nature and degree of recovery of grassland from the great drought of 1933 to 1940. Ecol. Monogr. 14: 393-479.

, AND W. E. Bruner. 1945. A seven-year quantitative study of succession in grassland. Ecol. Monogr. 15: 297-319.

$\longrightarrow$, AND W. W. Hansen. 1941. Regeneration of native midwestern pastures under protection. Univ. Nebraska Conserv. and Surv. Div. Bull. 23.

$\longrightarrow$, AND I. M. Mueller. 1942. Role of seedlings in recovery of midwestern ranges from drought. Ecology 23: 275-294. 